\title{
Bringing Deleuze's Philosophy into Discourse on Values Education and Quality Teaching: an Australian model
}

\author{
INNA SEMETSKY \& TERENCE LOVAT \\ School of Education, University of Newcastle, Australia
}

\begin{abstract}
The article examines the Australian national program of values education via the lens of Deleuze's philosophy. It argues that it is teachers with a genuine level of self-knowledge who can create the conditions conducive to best practice in schools. Both theoretically and empirically, quality teaching has demonstrated the power of the affective dimension exceeding cognitive knowledge of facts alone. Through an experiential approach to self-formation, we understand that values are implicit in practical life and that our knowledge of them - the core of values-education - lies in the ability to participate in the unfolding experiences.
\end{abstract}

The recent Australian Government's 'Values Education Good Practice Schools Project' (VEGPSP) Stages 1 and 2 Reports (Department of Education, Science and Training [DEST], 2006; Department of Education, Employment and Workplace Relations [DEEWR], 2008) concluded that a wellconstructed values education has potential for profound effect on the whole of an educational system, affecting such variables as student achievement, school ethos, teacher practice, classroom climate, student attitudes and behaviours, and parental and community connections. These findings were further confirmed by a government-funded study (Lovat et al, 2009) that applied empirical means to test and measure the conclusions drawn by VEGPSP. The current Australian National Framework for Values Education (DEST, 2005) comprises a set of nine values which are regarded as core values for guiding values education in all Australian schools, government and nongovernment. The values are listed as follows: 1. Care and Compassion; 2. Doing your Best; 3. Fair Go (Fairness); 4. Freedom; 5. Honesty and Trustworthiness; 6. Integrity; 7. Respect; 8. Responsibility; 9. Understanding, Tolerance and Inclusion. The VEGPSP reports illustrated the dynamics of the reciprocal interaction of values education and best practice pedagogy, or quality teaching.

Structured as a 'bottom-up' exercise (rather than imposing 'top-down', centrally administered directives on schools), Stage 2 of the project ran from 2006 to 2008 and involved 25 school clusters (152 schools altogether) that designed their specific values education projects to meet their local needs and to further inform the development and uptake of good practice in values education generally. The schools applied the National Framework to local contexts and environments and then reported on this implementation as a learning process. Curriculum Corporation, which managed the project for the Government, has used the meta-evaluation methodology to come up with 10 principles grounded in 10 modes of good practice in order to summarize the report. Among these principles is one that conforms with the notion of inculcation of values through explicit teaching, defined as the necessity to overtly and 'explicitly teach values so students know what the values mean and how the values are lived' (DEEWR, 2008).

Yet, the theoretical dimension as the would-be rationale for choosing the particular aforementioned values, as well as developed pedagogical/methodological approaches for their teaching, are noticeably missing in the Framework and appear merely as arcane situational variables for educators. This is despite the fact that the importance of investigating specifically theoretical foundations for values education was stressed at a number of National Values Education 
Forums, sponsored by the previous Australian Government as part of its nearly $\$ 30$ million commitment to a national values education program. Some glimpse into the history and philosophy of education might have informed the policy makers that it was originally Socrates who problematized the question about whether virtues can be explicitly taught at all! The problematic of the learning paradox (as it has been called) has long troubled both philosophers and educators (e.g. Bereiter, 1985; Petrie, 1991; Prawat, 1999; cf. Semetsky, 2005, 2009).

In this context, and as a critical while sympathetic reflection on the Australian values education context, the present article will analyse Gilles Deleuze's philosophy. The recent volume Theory for Education (Dimitriadis \& Kamberelis, 2006) devotes a chapter to Deleuze and Guattari, among other theorists ranging from Bakhtin to Bourdieu to bell hooks, as well as to Lacan and Vygotsky. Deleuze's philosophical method does not rely on abstract principles but aims 'to bring into being that which does not yet exist' (Deleuze, 1994, p. 147), thereby implicitly addressing the future-oriented path to knowledge as embedded in practical and pragmatic (Semetsky, 2006, 2008) action, in our very praxis (Semetsky \& Lovat, 2008). A particular way of knowing embedded in ethical action is derived from a necessary commitment to ongoing critical appraisal - reflection or evaluation - of the nature of knowledge and the function of the processes of knowing, to the sources of our knowledge and to the uncovering in our very experience of partial, skewed or blatantly fallacious evidence so as to finally arrive at self-knowing. A major assumption behind this article's conceptualizations is that only teachers with a genuine level of self-knowledge who have deeply internalized the values that with all good conscience they wish their students to share would be capable of creating the conditions conducive to best practice in the formal environment of contemporary schooling. (The devil's advocate would point out here that the circle of the infinite regress - namely, how do teachers acquire those values that subsequently become their second nature? - still appears to lurk in the background!)

It was the Carnegie Corporation's Task Force on Learning (1996) that in many ways impelled the modern era of quality teaching. It represented a turning point in the dominant, rather pessimistic conceptions placed on the role of the school and, in turn, on the power of teaching to effect change in student achievement. It utilized a body of research knowledge that showed flaws in earlier conceptions concerning the limited power of schooling to impact positively on student development and, hence, influence moral character. The implausibility and inadequacy of a valuesneutral approach being taken to such an inherently values-filled endeavour as education proved itself false. The Carnegie Task Force made the significant point that, while heritage and upbringing could make a difference to the ease with which new forms of learning could be attained, they were in no way certain predictors of success. In the search for successful restructuring of schools for the benefit of student achievement, Linda Darling-Hammond (1996, 1998, 2000; Darling-Hammond \& Youngs, 2002), herself a member of the Carnegie Task Force, engaged in intensive work that underlined the crucial role of the teacher.

Consistent with the era of quality teaching which the report in some ways ushered in, the final onus was placed on the school (especially the early years of school) and the teacher to make the difference. Students' environment, their very experience, was thus posited (even if not in those very words) as a difference that itself, if we use a famous phrase by Gregory Bateson (Bateson, 2000), can make a difference. In line with the work of Fred Newmann et al (1996), this would mean restructuring the whole culture of learning for the benefit of student achievement, and would involve a number of pedagogical strategies and techniques used by teachers. These include catering for the diverse needs of students; organizing of schools for the express purpose of student holistic achievement (school coherence); professional development of teachers; as well as the creation of a trustful, supportive school environment. Thus, development of the whole person was seen to require implicit modelling and explicit pedagogy as one action.

The idea of values education has the potential to go to the very heart of quality pedagogy by focusing teachers' attention on those features of their professional practice that have most impact, namely the affective qualities of care, mutual respect, fairness and positive relationships with students. Quality teaching has demonstrated the power of the affective dimension to exceed cognitive knowledge of facts alone (Lovat, 2005, 2009, 2010; Lovat et al, 2010; Semetsky, 2009, 2010a). It is specifically an affective dimension, as it pertains to Deleuze's philosophy and as it 'affects' the construction of our very subjectivities in practice, which is to be further analysed in this 
article so as to inform future decisive policies which may be undertaken by Australian (and not only Australian) policy makers.

Affirming a fundamental encounter with some novel experience against prior recognition, Deleuze posits the task of philosophy as the creation of concepts within a socio-cultural milieu. New concepts are to be created, epistemologically, and the states of affairs are to be evaluated, ethically, so that we can become capable of extracting from them new non-preexistent concepts, meanings and values. However, how efficacious are those new concepts going to be? The possible answer to this question accords with the pragmatic character of the whole of Deleuzian thought; that is, rather than attempting to generalize the politics of Deleuze's philosophy, we can posit a question, as Hardt (1993) did in his study on Deleuze: 'What can Deleuze's thought afford us? What can we make of Deleuze? In other words, what are the useful tools we find in his philosophy for furthering our own political endeavors?' (1993, p. 19), or for that matter, for advancing and broadening our inquiry into the policy futures for education.

The states of things, for Deleuze, are what he called qualitative multiplicities, or relational entities, the analysis of which as a task of philosophy ultimately leads to the invention or construction of concepts anew. Subjectivation is a relation to oneself; it is also a multiplicity which is recreated in experience; as such it cannot be based on any pre-existent codification or derive from higher principles. Self-formation (as a task of moral or values education, in the context of this article) is experiential and experimental, embedded in action, in practice. Deleuze recognizes the micropolitical dimension of culture as a contextual, experiential and circumstantial site where subjects are situated and produced. As a qualitative multiplicity, subjectivity does not presuppose identity but is grounded in difference indeed. It is the human experience permeated by difference, which can produce a shock to our habitual thinking, that is to be considered as a condition of possibility, or 'the inventive potential' (Massumi, 1992, p. 140), of becoming other than the present self: we - teachers and students alike - do learn from experiences. least:

A novel concept is not solely rational but empirical, experimental. It involves, for Deleuze, at

two other dimensions, percepts and affects. Percepts aren't perceptions, they're packets of sensations and relations that live on independently of whoever experiences them. Affects aren't feelings, they are becomings that spill over beyond whoever lives through them (thereby becoming someone else). (Deleuze, 1995, p. 127)

Rather than being thought a priori by a knowing subject, it is an objective capacity to affect and be affected that makes us think and learn: the affects are embedded or enfolded in lived experience. We experience some difference in the environing culture; and it is this difference, a dissonance that forces us to start thinking; such a difference is not yet conceptualized but can only be 'grasped in a range of affective tones' (Deleuze, 1994, p. 139). An encounter with experiential difference is intense, and the intensity of difference is a function of affect as complementary to purely cognitive understanding.

The intensive capacity 'to affect and be affected' (Deleuze \& Guattari, 1987, p. xvi) is part and parcel of the dynamic subject's complex rules of formation. The production of subjectivity includes an encounter with pure affect as if it were an autonomous and real being. The powerful intensity of such an encounter marks the passage between the experiential states of the body and accordingly affects the body's capacity for action. The body, for Deleuze (borrowing from Spinoza), is both physical and mental as well as both cognitive and affective; and the affect is not just a feeling or emotion but a real material force influencing the body's mode of existence in the world: its potential power. The latter is defined as a capacity to multiply and intensify connections. Because a practical situation itself involves our as yet unrealized experiences, Deleuze's conception of philosophical thinking is based on the quasi-empirical method of mapping a difference arising between several experiential courses of events.

It is the force of thinking as, importantly, originating in real experience (called by Deleuze the Outside) that 'must throw it [thinking] into a becoming-active' (Deleuze, 1983, p. 108). These outside forces belong to the socio-cultural, public, milieu and not to a private world of mind of a Cartesian subject forever separated from the objects of the Outside. The value of knowledge as the product of such thinking is in its practical import; that is, the way we will act, think, and feel - in short, assign value to our own experience in the world - as the pragmatic effect of the said 
knowledge which, as we said, is affected by experience. An affective dimension, by constituting the very core of concepts, in turn 'affects' the notion of truth which in Deleuze's philosophy may also be considered a dynamic concept par excellence. Truth is not out there waiting to be discovered in its pre-existing state to be contemplated, but 'has to be created in every domain' (Deleuze, 1995, p. 126) in our practical life and is bound to be affected by, and to affect in turn, a series of falsifications. In fact, there is no other truth, for Deleuze than 'the creation of the New: creativity, emergence' (Deleuze, 1989, p. 147).

Subjectivation, functioning in a mode of creative potential close to the Foucauldian 'art of oneself that's the exact opposite of oneself (Deleuze, 1995, p. 115), becomes manifest in one's ability to express oneself passionately and freely, and 'has little to do with any subject. It's to do, rather, with an electric or magnetic field, an individuation taking place through intensities ... it's to do with individuated fields, not persons or identities' (Deleuze, 1995, p. 98). The power to be free is implicit in Deleuze's philosophy and is essentially different 'from the standard liberal concepts of positive and negative freedom' (Patton, 2000, p. 83). Liberal thought, rather than taking into consideration the overall conditions of change as a whole, assigns to an individual Self the centrestage of a volitional and constituting subject, thus conflating a whole with its single part. By contrast, Deleuze's post-structuralist 'subject' continuously exercises the critical freedom of constituting herself which takes place through social fields, the very notion of the field implying the collective and distributed nature of the subjectivity-in-process as always already becoming-other. For Deleuze and Guattari, liberation does not mean being free to manipulate a supposedly external reality (in the manner of technical control) by the subject that would have been located outside of that very arrangement which appears as if she herself imposed it on the world. Instead liberation consists in the free expression of forces so that the subject - her very nature - becomes produced in practice.

Subjectivity is described by means of one's expressing oneself in order 'to bring something to life, to free life from where it's trapped, to trace lines of flight' (Deleuze, 1995, p. 141), to break down old methods and to break into new territories and new modes of action, such a process aptly identified by means of deterritorialization and reterritorialization respectively. The Deleuzian subject, in a process of self-creation as becoming-other, is not socially isolated but always open to material forces that construe it by means of interactions with the Outside, the latter consisting of 'political creations and social becomings: this openness is precisely the "producibility" of being' (Hardt, 1993, p. 120).

The production of subjectivity, for Deleuze, is effected by unfolding in a spiralling distributive process of becoming defined as 'an internalization of the outside. It is not a reproduction of the Same, but a repetition of the Different. It is not the emanation of an "I" but something that places in immanence the always other ... I do not encounter myself on the outside. I find the other in me' (Deleuze, 1988, p. 98). This deep and immanent internalization of 'the other' - that is, a full integration (cf. Semetsky, 2010b) of other people's beliefs, frames of reference, perspectives and values - is what ultimately would have led to values becoming shared, indeed. Such a process of subjectivation is far removed from centring on the so-called 'constituting' and knowing subject. Instead it is a production of subjectivity in experience by means of creating new concepts and inventing new possibilities of life; as such, the subject becomes constituted in a dynamic living process. Some shocking experiences (such as personal or collective crises) that one may encounter in life are expressions of the play of forces without which no transformation to one's authentic self by means of becoming-other would be possible. The world itself is folded and, as such:
we can endure it, so that everything doesn't confront us at once ... It's not enough for force to be exerted on other forces or to suffer the effect of those other forces, it has to be exerted upon itself too ... There's no subject, but a production of subjectivity: subjectivity has to be produced, when its time arrives ... The time comes once we've worked through knowledge and power; it's that work that forces us to frame a new question, it couldn't have been framed before. (Deleuze, 1995, pp. 112-114)

The self-reflective exertion of force upon itself not only leads to a production of subjectivity but also ensures its emergence at the new level 'equipped' with the newly created values as the function of experience, of learning. At this level there is neither a room for the old set of values, nor 
are eternal ones stored there. Ethics is inherent in a production of subjectivity, and subjectivation is 'ethical and esthetic, as opposed to morality' (Deleuze, 1995, p. 114). Deleuzian philosophy:

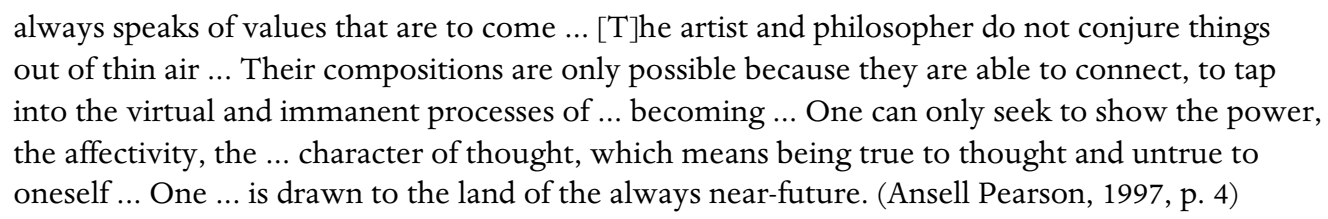

A seemingly paradoxical element of being untrue to oneself, whence one's self is always already a history and is situated in the individuating (yet always social as embedded in the environmental milieu) process of becoming, means that some outdated values that were once established will be transformed - that is, evaluated and changed when 'affected' by experience. It is the affective process of becoming - literally, becoming-other - that is a cornerstone of Deleuze's philosophy. In agreement with Deleuze's positing continuous creation of new concepts, the concept itself is described as the future constellation of an event, or the map's territory. The proverbial relationship between a map and a territory (again bringing to mind Gregory Bateson's conceptualizations) avoids both the trap of a local representation or the temptation of deconstruction: the territory implies the distributed - as Deleuze says, nomadic - character of concepts. During such experiential nomadic education (Semetsky, 2008) 'the map ... merges with its object, when the object itself is movement ... [and] the trajectory merges not only with the subjectivity of those who travel through a milieu, but also with the subjectivity of milieu itself, insofar as it is reflected in those who travel through it' (Deleuze, 1997, p. 61). This metaphor enables us to envisage the power of environment, of the whole of culture.

With real political and ethical vigour, Deleuze introduces a notion of nomadic becoming as an unorthodox process of thinking, knowing and practical self-formation. Nomadic inquiry supplements a narrow path of analytical knowledge with a broader format of diverse and spacious forms of mapping, employed in the methodologies of contemporary cultural studies. The nomadic methodology accords with the implied relation between practice and theory, in which the theorypractice nexus is defined by everyday engagements with knowledge production. This method considers every value judgement analogous to making a conjecture, which is to be tested in practice in the context of changing problematics of circumstances, situations and social conditions. Theory and practice are interrelated in that theory performs a practical function of being used for the revaluation of novel modes of existence through creating new and better-informed concepts and meanings in a critical self-reflective way. In a pragmatic sense, a number of possible consequences can never be fully exhausted and the process of becoming-other is theoretically unending.

Subjectivity therefore cannot be fixed except temporarily. Considering that teachers' subjectivities, in the framework of Deleuze's philosophy, are also embedded in a dynamic process of experiential learning, students cannot be approached from the position that John Dewey used to ironically dub a supreme dignity of adulthood. Subjectivity is irreducible to such notions as totality, unity or any prefixed self-identity. As affective, subjectivity expresses itself neither by means of progressive climbing toward the ultimate truth or the higher moral ideal, nor by looking for origins, even lost or deleted ones, but setting out to catch things where they were at work, in the middle: breaking things open, breaking words open' (Deleuze, 1995, p. 86). For Deleuze, thinking and living coalesce, as do cognitive and affective domains which are mutually enfolded: a new concept is created in the affective experience. It is an affect 'enfolded' in the experiential event permeated with difference; affects 'spill over' the confines of our habitual way of thinking so that we need to evaluate the situation by means of 'unfolding': this unorthodox " philosophy" comes full circle when the "subject" ... "orients" its own practical activity of interpretation, evaluation or orientation of the terms of experience within this universal matrix it has itself unfolded' (Joughin, 1992, p. 9). Nomadic subjectivities are always in the process of becoming; 'the life of nomad is the intermezzo' (Deleuze \& Guattari, 1987, p. 380), distributed at once between here and there, between now and then, 'always the day before and the day after' (Deleuze, 1995, p. 77).

By taking such an experiential approach to self-formation, we understand that values are implicit in practical life and that our knowledge of them - the crux of values-education - lies in our ability to participate in the unfolding experiences. The best teacher is therefore experience itself. The 
practical way of knowing engages both self and others at the level of the whole person. While maximizing the effects of quality teaching in a formal school environment indeed requires explicit attention to the values dimension that can be achieved through a well-crafted values education program, we should keep in mind that our experiences comprise an informal 'school' in which values are implicit. Our understanding of the role of the teacher, quality pedagogy and the power of values education are coalescing. No longer can values education be considered peripheral nor in any way the exclusive province of faith-based schooling. The nature, shape and purpose of values education has the potential to refocus the attention of the educational system on the fundamental item of all effective pedagogy, namely the subjectivity of a teacher and her life-experience. The real-life problems cannot be solved by means of Cartesian method through 'search for the clear and distinct' (Deleuze, 1994, p. 161) ideas. Rather, learning is 'infinite ... [and] of a different nature to knowledge' (Deleuze, 1994, p. 192): it is a process of self-knowing by means of inventing concepts in practice.

Recognizing the narrow instrumentalist view of education, Deleuze called for education of the senses by means of exploring the faculties of perception not limited to the passive reception of pure sense-data. His pluralism is a kind of constructivism because human interactions create a social network of self-other relations to be explored anew in the plurality of situations and contexts, the changing spatio-temporal dynamisms which demand a novel understanding of collective experiences - that is, creating or inventing a set of new concepts and meanings as a means for revaluation of experience, therefore constructing one's subjectivity in practice. It is this creative process that would be a genuine 'values education' according to Deleuze.

How can such nomadic education be implemented in practice? A creative teacher must take responsibility for her own actions and reactions, for the consciousness and the 'will that the event creates in us' (Deleuze, 1990, p. 148), as well as for understanding the perspective of the other because 'there is something to be learned from each person involved' (Gibbs, 2000, p. 160). In the process we will be confronting ourselves, including our own comfort zones of knowing; those familial, cultural, religious and dispositional preferences that, having so far provided a feeling of inner security, have become part of our habitual identity. Yet, Deleuze's transformational pragmatics presupposes breaking out of old habits and into new, as yet unknown, territories that abound in practical actions.

Becoming is by definition an experiment with what is new; that is, coming into being, becoming. Experience constitutes a complex place, and it is our experimentation on ourselves as enfolded in the world that, for Deleuze, is our only identity. It is an experience that provides real conditions for our intellectual and moral growth; however, not at all as a property of hierarchical structuring; Deleuze rejected 'the principle of linear progressive "building up knowledge"'(Deleuze, 1995, p. 139). Rather than discovering the pre-existent domain of truth(s), learning consists in the experimental and heterogeneous production of meanings as the newly created concepts. Deleuze addressed his philosophy as both critical and clinical, because the evaluation of experience proceeds by self-reflective critical thinking. Critical (cognitive) and clinical (affective) dimensions coalesce. It is the ethical task as a revaluation of experience that supplements critical thinking and understanding with its clinical dimension. And it is clinical not only by virtue of it being an assessment, as if a diagnosis, of a particular mode of existence by means of assessing the latter's symptoms but also a sort of prognosis by means of evaluating, hence anticipating, the range of possible future directions.

The dynamics of an unfolding experience is a process that includes both the actual past and potential future. It is along a particular 'line of flight' (Deleuze's neologism) that novelty comes into being, or becomes when it is created in this very experience. For Deleuze, 'once one ventures outside what's familiar and reassuring, once one has to invent new concepts for unknown lands, then methods and moral systems break down' (Deleuze, 1995, p. 103), giving room to the practical creation of values. The epistemic subjectivity is simultaneously ethical because she becomes able to see her own life-world as just one that needs to function in a myriad of life-worlds of others. The creation of concepts (pedagogy of the concept, as Deleuze called this process) entails the dimension of values because it aims towards transcending or overcoming one's mode of useless knowledge, preconceived beliefs, or old habits of existence. Learning then becomes a value-able encounter with practical difference embedded in the relational dynamics of teachers and students alike. For Deleuze, the very concept of 'the notion of value implies a critical reversal ... The problem of 
critique is that of the value of values, of the evaluations [of lived experiences and practical actions] from which their value arises, thus the problem of their creation' (Deleuze, 1983, p. 1).

In the context of quality teaching, it is only under the conditions of critical and self-reflective ways of knowing that the transformation to new beliefs and actions in the world becomes possible. The process of self-knowing is paved with values and inevitably requires us to establish a particular culture of respect, trust and care between students and teachers without imposing preconceived values onto students (onto others). Conceived as such, values education and quality teaching will coalesce in practice, thus supplementing formal schooling with its often-missing element of values.

\section{References}

Ansell Pearson, K. (1997) Deleuze Outside/Outside Deleuze, in K. Ansell Pearson (Ed.) Deleuze and Philosophy: the difference engineer, pp. 1-22. London: Routledge.

Bateson, G. (2000) Steps to an Ecology of Mind: collected essays in anthropology, psychiatry, evolution, and epistemology. Chicago: University of Chicago Press.

Bereiter, C. (1985) Towards a Solution of the Learning Paradox, Review of Educational Research, 55(2), 201-226.

Carnegie (1994) Years of Promise: a comprehensive learning strategy for America's children. Executive summary. http: / /www.carnegie.org/sub/pubs/execsum.html

Darling-Hammond, L. (1996) What Matters Most: a competent teacher for every child, Phi Delta Kappa, 78(3), 193-200.

Darling-Hammond, L. (1998) Teachers and Teaching: testing policy hypotheses from a National Commission report, Educational Researcher, 27(1), 5-15.

Darling-Hammond, L. (2000) Teacher Quality and Student Achievement: a review of state policy evidence, Education Policy Analysis Archives, 8(1), 1-50.

Darling-Hammond, L. \& Youngs, P. (2002) Defining 'Highly Qualified Teachers': what does 'scientificallybased research' actually tell us? Educational Researcher, 31(9), 13-25. http: / / dx.doi.org/10.3102/0013189X031009013

Deleuze, G. (1983) Nietzsche and Philosophy. New York: Columbia University Press.

Deleuze, G. (1988) Spinoza: practical philosophy, trans. R. Hurley. San Francisco: City Lights Books.

Deleuze, G. (1989) Cinema 2: The Time-Image, trans. H. Tomlinson \& R. Galeta. Minneapolis: University of Minnesota Press.

Deleuze, G. (1990) The Logic of Sense, trans. M. Lester. New York: Columbia University Press.

Deleuze, G. (1994) Difference and Repetition, trans. P. Patton. New York: Columbia University Press.

Deleuze, G. (1995) Negotiations 1972-1990, trans. M. Joughin. New York: Columbia University Press.

Deleuze, G. (1997) Essays Critical and Clinical, trans. D.W. Smith \& M. Greco. Minneapolis: University of Minnesota Press.

Deleuze, G. \& Guattari, F. (1987) A Thousand Plateaus: capitalism and schizophrenia, trans. B. Massumi. Minneapolis: University of Minnesota Press.

Deleuze, G. \& Guattari. F. (1994) What is Philosophy?, trans. H. Tomlinson \& G. Burchell. New York: Columbia University Press.

Department of Education, Employment and Workplace Relations (DEEWR) (2008) At the Heart of What We Do: values education at the centre of schooling. Report of the Values Education Good Practice Schools Project - Stage 2. Melbourne: Curriculum Corporation. Available at: http:/ / www.curriculum.edu.au/values/val_vegps2_final_report,26142.html

Department of Education, Science and Training (DEST) (2005) National Framework for Values Education in Australian Schools. Canberra, Australian Government Department of Education, Science and Training. http://www.valueseducation.edu.au/verve/_resources/Framework_PDF_version_for_the_web_left_c olumn_file_link.pdf

Department of Education, Science and Training (DEST) (2006) Implementing the National Framework for Values Education in Australian Schools: Report of the Values Education Good Practice Schools Project Stage 1: Final report, September 2006. Melbourne: Curriculum Corporation.

http: / / www.valueseducation.edu.au/values/ default.asp?id=16381

Dimitriadis, G. \& Kamberelis, G. (2006) Theory for Education. New York and London: Routledge.

Gibbs, R. (2000) Why Ethics? Signs of Responsibilities. Princeton, NJ: Princeton University Press. 
Hardt, M. (1993) Gilles Deleuze: an apprenticeship in philosophy. Minneapolis: University of Minnesota Press.

Joughin, M. (1992) 'Translator's Preface', in G. Deleuze (1992) Expressionism in Philosophy: Spinoza, trans. M. Joughin. New York: Zone Books.

NSW Lovat, T.J. (2005) Values Education and Teachers' Work: a quality teaching perspective. National Values Education Forum, Australian Government Department of Education Science and Training. http:/ / www.valueseducation.edu.au/values / default.asp?id $=8753$

Lovat, T. (2009) Values Education and Quality Teaching: two sides of the learning coin, in T. Lovat $\&$ R. Toomey (Eds) Values Education and Quality Teaching: the double helix effect, pp. 1-12. Dordrecht: Springer.

Lovat, T. (2010) Synergies and Balance between Values Education and Quality Teaching, Educational Philosophy and Theory, 42(4), pp. 489-500. http: / / dx.doi.org/10.1111/j.1469-5812.2008.00469.x

Lovat, T., Toomey, R. \& Clement, N. (Eds) (2010) International Research Handbook on Values Education and Student Wellbeing. Dordrecht: Springer.

Lovat, T., Toomey, R., Dally, K. \& Clement, N. (2009) Project to Test and Measure the Impact of Values Education on Student Effects and School Ambience. Report for the Australian Government Department of Education, Employment and Workplace Relations. (DEEWR) by the University of Newcastle, Australia. Canberra: DEEWR. http:/ / www.valueseducation.edu.au/values/val_articles, 8884.html

Massumi, B. (1992) A User Guide to Capitalism and Schizophrenia: deviations from Deleuze and Guattari. Cambridge, MA: The MIT Press.

Newmann, F. \& Associates (1996) Authentic Achievement: restructuring schools for intellectual quality. San Francisco: Jossey Bass.

Patton, P. (2000) Deleuze and the Political. London and New York: Routledge. http: / / dx.doi.org/10.4324/9780203424483

Petrie, H. (1991) The Dilemma of Inquiry and Learning. Chicago: University of Chicago Press.

Prawat, R. (1999) Dewey, Peirce and the learning paradox, American Educational Research Journal, 36(1), 47-76.

Semetsky, I. (2005) Learning by Abduction: a geometrical interpretation, SEMIOTICA, 157(1-4), 199-212.

Semetsky, I.. (2006) Deleuze, Education and Becoming. Rotterdam: Sense Publishers.

Semetsky, I. (Ed.) (2008) Nomadic Education: variations on a theme by Deleuze and Guattari. Rotterdam: Sense Publishers.

Semetsky, I. (2009) Deleuze as a Philosopher of Education: affective knowledge/effective learning, The European Legacy: toward new paradigms, 14(4), 443-456.

Semetsky, I. (2010a) The Folds of Experience, or: constructing the pedagogy of values, Educational Philosophy and Theory, 42(4), 476-480. http://dx.doi.org/10.1111/j.1469-5812.2008.00486.x

Semetsky, I. (2010b) Towards an Ethics of Integration in Education, in T. Lovat, R. Toomey \& N. Clement (Eds) International Research Handbook on Values Education and Student Wellbeing, pp. 319-336. Dordrecht: Springer.

Semetsky, I. \& Lovat, T. (2008) Knowledge in Action: towards a Deleuze-Habermasian critique in/for education, in I. Semetsky (Ed.) Nomadic Education: variations on a theme by Deleuze and Guattari, pp. 171-182. Rotterdam: Sense Publishers.

INNA SEMETSKY is a Research Academic at the University of Newcastle, Australia. She has published three books on the topics of Deleuze, educational theory and semiotics as well as numerous articles, book chapters, and encyclopedia entries. Her book, Re-symbolization of the Self: human development and tarot hermeneutic, is published in 2011 (Sense Publishers, series 'Transgressions: cultural studies and education') and will be followed by a sequel titled The Edusemiotics of Images: essays on the art science of tarot in the series 'Educational Futures: rethinking theory and practice'. Correspondence: Inna Semetsky, School of Education, University of Newcastle, NSW 2308, Australia (inna.semetsky@newcastle.edu.au).

TERENCE LOVAT is Emeritus Professor at the University of Newcastle, Australia and Academic Dean of Broken Bay Institute of Theology, Sydney. He is chief editor of International Research Handbook on Values Education and Student Wellbeing (Springer, 2010) and chief author of Values Pedagogy and Student Achievement (Springer, 2011). He is author of over 100 refereed articles and 
Deleuze's Philosophy and Australian Teaching

academic book chapters across the areas of values education, religious education and curriculum theory, as well as Islam and its relations with non-Muslim religions and traditions. Correspondence: c/o Pro Vice-Chancellor Unit (Education and Arts), The University of Newcastle, NSW 2308, Australia (terry.lovat@newcastle.edu.au). 